\title{
THE USE OF PHRASAL VERBS IN ENGLISH LANGUAGE RESEARCH PROPOSALS BY VIETNAMESE M.A. STUDENTS
}

\author{
Tran Phan Ngoc Tu* ${ }^{*}$, Tran Quoc Thao ${ }^{2}$ \\ 1. Bui Thi Xuan High School, \\ 242 Bui Thi Xuan Street, Ward 2, Da Lat, Lam Dong province \\ 2. Ho Chi Minh City University of Technology (HUTECH), \\ 475 A Dien Bien Phu Street, Ward 25, Binh Thanh, Ho Chi Minh City \\ Received 25 December 2018 \\ Revised 26 May 2019; Accepted 30 July 2019
}

\begin{abstract}
Phrasal verbs are highly common in and typical of the English language. However, ESL/EFL students in different contexts seem to avoid using them in their academic writing, especially in English applied linguistics. This study aims at investigating the use of phrasal verbs in the research proposals among Vietnamese M.A. students who were studying at one university in Vietnam. Nineteen research proposals chosen in this study cover 5 major themes, including TESOL Methodology, Discourse Analysis, Linguistics, Literature, and Translation. The data were analyzed by the software AntConc version 3.7.8. The findings of the study indicated that the participants had a tendency to avoid using phrasal verbs in their M.A. research proposals. Furthermore, they did not utilize many among top 100 common phrasal verbs in BNC by Gardner and Davies (2007). With respect to the functions of phrasal verbs, Vietnamese M.A. students used different subcategories in syntax and semantics. Nevertheless, they paid more attention to the use of transitive and inseparable phrasal verbs as well as phrasal verbs with semi-idiomatic and fullyidiomatic meanings.
\end{abstract}

Keywords: phrasal verbs, M.A. research proposals, syntax, semantics

\section{Introduction}

Along with the widespread use of lexicon, phrasal verbs serve as an integral domain of linguistic phenomena. Celce-Murcia and Larsen-Freeman (1999); Gardner and Davies (2007); Siyanova and Schmitt (2007) agree that phrasal verbs are considered one of the most challenging phenomena in the English language. Some researchers express different viewpoints on phrasal verbs in linguistics

\footnotetext{
* Corresponding author. Tel.: 84-919389398
}

Email: tranphanngoctubtx@gmail.com from various angles. Gardner and Davis (2007) state that phrasal verbs, which are composed of two major elements: one openclass item (the verb) and one closed-class item (the particle), are referred to as the multiword middle ground of lexis and grammar. Davies (2009) indicates that phrasal verbs are on the interface betweeen the syntax and semantics aspects. Ellis (1985) emphasizes the significance of phrasal verbs in syntax and phonology. It is, notwithstanding, noticed that in the English language, phrasal verbs are considered one of the most distinctive and creative features. However, the use of phrasal 
verbs in academic writing may not receive much attention from students in general.

Although phrasal verbs are largely found in spoken and informal English language, several researchers such as Fletcher (2005) and McCarthy and O'Dell (2004) assume that phrasal verbs universally appear in written and formal English. Additionally, Fletcher (2005) claims that phrasal verbs can also appear in all types of written text and play as an effective tool to convey the writer's messages. While native speakers seem to use phrasal verbs frequently because of their "characteristics of flexibility, practicability, adaptability and efficiency" (Chen, 2007, p. 350), non-native speakers find it difficult to acquire them owing to the permeability (e.g., Celce-Murcia \& Larsen Freeman, 1999; Darwin \& Gray, 1999; Moon, 1998).

Phrasal verbs are also challenging to Vietnamese students because of the following reasons. One reason is that English phrasal verbs are characterized by their extreme uniqueness when compared with Vietnamese. As Celce-Murcia and Larsen-Freeman (1999) assure, phrasal verbs rarely occur in nonGermanic language. While there appear many phrasal verbs in English, we cannot find phrasal verbs in Vietnamese. Another reason is that phrasal verbs in English have a wide range of variability in syntax and semantics. The fact that phrasal verbs have various variabilities in syntax and sematics makes students who learn English as second language face challenges (Sinclair, 1989). When using phrasal verbs, students have to concentrate on different factors, including meaning, form, and use. As Hasbun (2005) indicates, "learners need to keep in mind that these multi-word units are necessary if natural communication is to happen. For example, in order to acquire phrasal verbs, students need to understand their form, their meaning and their use" (p. 2). Moreover, the prejudice of their use for colloquial and informal context is one reason that students do not use phrasal verbs so often (Dagut \& Laufer, 1985; Laufer \& Eliasson, 1993). Furthermore, the diversity in the form and the meaning is another reason why phrasal verbs are challenging to students (Gardner \& Davies, 2007). For example, some phrasal verbs have fixed structures while others are more flexible with the movement of particles in structures. In conclusion, these afore-mentioned reasons might prevent Vietnamese students from using phrasal verbs in formal contexts.

In terms of research on phrasal verbs in Vietnam, some studies have been implemented so far. For instance, Nguyen and Phan (2009) and Huynh andVo (2015) identify the beneficial impacts of conceptual metaphors on teaching phrasal verbs to Vietnamese students. However, little research discussing the use of phrasal verbs in academic writing, especially in M.A. research proposals, has been operated.

The present study focuses more on academic writing, especially in research proposals because it is obvious that academic writing plays integral roles in higher education. In academic writing, Gocsik (2005) clarifies that in order to understand academic writing, it is imperative to base on three main concepts: (1) academic writing is "writing done by scholars for other scholars" (p. 1); (2) academic writing mainly focuses on the topics or questions in the favour of the academic community; (3) academic writing aims at meeting the academic readers' expectations. In terms of research proposals, Saunders, Lewis and Thornhill (2016) state that it is of essence to follow academic writing styles. In order to attain profound insights of the usage of phrasal verbs among students when they write their research proposals, this study aims at examining this issue among M.A. students at one university in Vietnam. Two research questions to be addressed in this study are as follows: 
1. What phrasal verbs are used in English Applied Linguistics research proposals written by Vietnamese M.A. students at one Vietnam-based university?

2. What are the functions of phrasal verbs used in English Applied Linguistics research proposals written by Vietnamese M.A. students at one Vietnam-based university?

\section{Literature review}

\subsection{Definitions of phrasal verbs}

According to Collins Cobuild of Dictionary of Phrasal verbs, phrasal verbs are defined as "combination of verbs with adverbial and prepositional particles". In some cases, phrasal verbs are given different names such as "compound verb", "verb-adverb combination" or "verb-particle construction". Some of common verbs used in phrasal verbs are "come", "go", "look", "make", "put", "take"... and some popular particles that form phrasal verbs are "at", "away", "down", "off", "on", "out", "up" ... When the verbs combine with the particles, the meanings of the combination, in most cases, cannot be inferred from the meanings of the two separate parts. Take "put out" as an example. Oxford Advanced Learner Dictionary defines "put" as "to move something into a particular place or position" and "out" means "away from the inside of a place or thing". However, one of the meanings of "put out" is "to leave a port". It is concluded that not only are phrasal verbs the basic structures of utterances, but they also exist as complete meaningful units. Stephen (2002) defines a phrasal verb as a combination of a verb and one or two particles, all of which function as a single word. An adverb, a preposition or even both adverb and preposition can act as particles. Quirk et al. (1985) and Biber et al. (1999) indicate that phrasal verbs have both the semantic and syntactic elements. In short, phrasal verbs are the combination of verbs with particles.

\subsection{Semantic functions of phrasal verbs}

In terms of semantic elements, according to Downing and Locke (2006), the meanings of phrasal verbs are split into three major subcategories, including non-idiomatic, semiidiomatic, and fully idiomatic. With respect to non-idiomatic meaning, learners can understand the meanings of the phrasal verbs easily by using the combination of the individual lexical meaning of the verb and the particle. For example,

(1) I ran across the street. (Oxford Living Dictionaries)

In semi-idiomatic phrasal verbs, the verb keeps its literal meaning while the particle serves the intensifying function. For instance,

(2) I need to change and clean up. (Oxford Advanced Learners Dictionary)

It is commonly difficult to identify the meanings of fully idiomatic phrasal verbs because they have new meanings, which cannot be deduced from the meanings of each part in the combination. Some examples of "take+particle" (Oxford Advanced Learners Dictionary) are in the following sentences:

(3) Your daughter doesn't take after you at all. (to look or behave like an older member of your family, especially your mother or father)

(4) We were simply taken apart by the other team. (to defeat somebody easily in a game or competition)

(5) He was homeless, so we took him in. (to allow somebody to stay in your home)

(6) Workmen arrived to take down the scaffolding. (to remove a structure, especially by separating it into pieces)

(7) It has been suggested that mammals took over from dinosaurs 65 million years ago. (to become bigger or more important than something else; to replace something) 
As can be seen in the examples above, when the particles change, the meanings of the verb "take" in the phrasal verbs change as well. It is because "they differ from mainstream adverbs in having very little semantic content" (Börjars \& Burridge, 2010, p. 99).

\subsection{Syntactic functions of phrasal verbs}

In syntax, phrasal verbs can be characterized by transitive, intransitive, seperability and inseperability (Lessard-Clouston, 1993). This can be shown by the following examples from Collin Cobuild Dictionary:

Transitivity: (8) She asked me to fill in the form.

Intransitivity: (9) The young secretary always turns up early. (arrives)

Separability:

(10) I write the lesson down.

(11) I write down the lesson.

Inseparability: (12) I'm counting on you to send me the information by the end of the day.

\subsection{The use of phrasal verbs}

Phrasal verbs appear in all aspects of language use, especially in written form of communication. In the research on the 100-million-word BNC, Garner and Davies (2007) identify that two phrasal verbs occur in every 192 words per page of written text on average, which demonstrate the frequency of phrasal verbs in language use. However, owing to the complexity in terms of syntax and semantics, they are notoriously difficult to students who learn English as a second language (Sinclair, 1989). The previous empirical studies (Dagut \& Laufer, 1985; Hulstijn \& Marchena 1989; Laufer \& Eliasson 1993) show that learners have a tendency to use one-word verbs instead of phrasal verbs. One of the reasons for this is that they do not have a profound understanding of the syntactic and semantic elements of phrasal verbs.

\subsection{Previous studies on phrasal verbs}

Many researchers have recently focused on phrasal verbs. Regarding the use of phrasal verbs, a study conducted by Faharol, Norlizawati and Hifzurrahman (2011) in a secondary school in Kedah, Malaysia attempted to explore the word choice between phrasal verbs and one-word verbs among students. In the study, the participants are 40 students aged 16 years old. With the use of questionnaires and interview, the finding of the study revealed that students preferred to use both phrasal verbs and one-word verbs. The students, however, tended to avoid unfamiliar phrasal verbs. Liao and Fukuya (2002) conducted a study on figuring out the avoidance of using English phrasal verbs among Chinese learners concerning their advanced and intermediate levels, phrasal verbs types and test types. The findings of the study revealed that both advanced and intermediate learners tended to avoid using phrasal verbs and prefer using one-word verbs and to produce less figurative than literal phrasal verbs. Furthermore, Chinese learners paid more attention to the semantic nature of phrasal verbs in translation tests.

In order to identify the most frequent phrasal verbs, Trebits (2009) implemented a study to investigate the use of phrasal verbs in English language European Union documents. Approximately 200,000 words were tested in the corpus of EU English to find out the most frequent phrasal verbs. The results showed that there were 25 top phrasal verbs of all phrasal verbs occurred in the corpus. The frequency of phrasal verbs in documents in European Union was similar to that in written academic English.

In the context of Vietnam, Tran and Duong (2013) conducted a study on the use of hedges in academic writings in both sections of research article in Applied Linguistics 
and Chemical Engineering. The findings of this study showed that the use of hedges in Applied Linguistics was more frequent than that in Chemical Engineering. Huynh et al. (2015) investigated the methods to teach and learn phrasal verbs using conceptual metaphor at Tra Vinh University. The participants, first year undergraduate students majoring English, were taught with traditional methods and conceptual metaphors. Afterwards, their understandings about phrasal verbs were tested by pre-tests and post-tests. The findings affirmed that the conceptual metaphors brought more benefits on comprehension than the traditional instructions. However, there has been little research on the use of phrasal verbs in English Applied Linguistics research proposals by Vietnamese M.A. students.

\section{Methodology}

\subsection{Research design and data}

This study employed qualitative and quantitative methods to investigate the use of phrasal verbs in research proposals produced by students of Master of Arts (M.A.) in English Applied Linguistics. The former is for analyzing the frequency of phrasal verbs, while the latter is for scrutinizing the functions of the examined phrasal verbs.

The data used in this study was the 19 research proposals of M.A. in English Applied
Linguistics. The reason for selecting M.A. students was to ensure that all the participants had a moderately high level of English proficiency based on results of their MA entrance exams (English language profiency tests). Furthermore, the corpus consisting of research proposals of M.A. in English Applied Linguistics showed the relatively equal level of the use of English among M.A. students. Furthermore, the choice of research proposals of Master of Arts was to ensure that the writing styles was of academic writing as Hillard and Harris (2003) indicate that "Academic writing names the kind of intellectual prose students are expected to produce as undergraduates: writing that takes a sustained interest in an issue under consideration and gathers much of its evidence from a careful reading of sources" (p.17). As can be seen in Table 1, those who wrote research proposals were 19 M.A. students, including 5 males and 14 females, aged from 20 to over 40 and had experience in teaching from under 5 years to over 10 years in primary schools, lower secondary schools, upper secondary school and universities, accounting for 5.3\%, 57.9\%, $31,6 \%$ and $5.3 \%$, respectively. As described in Table 1, the copus was composed of over 99 thousand words representing the common and frequent patterns of written English on different major themes such as Linguistics, Literature, Translation, Discourse Analysis, and TESOL methodology.

Table 1. The corpus of transcripts

\begin{tabular}{cccc}
\hline Type & Type of research & Total of words & $\%$ \\
\hline TESOL Methodology & 10 & 52946 & 53.3 \\
\hline Discourse analysis & 4 & 23473 & 23.6 \\
\hline Linguistics & 3 & 16891 & 17 \\
\hline Translation & 1 & 2360 & 2.4 \\
\hline Literature & 1 & 3677 & 3.7 \\
\hline Total & 19 & 99347 & 100 \\
\hline
\end{tabular}


The purpose of this study is to examine the use of phrasal verbs in the M.A. students research proposals, so the choosen samples must meet the following criteria:

- The students must complete all of the compulsory subjects in the M.A. courses before writing the research proposals.

- The proposals must be written by M.A. students in English Applied linguistics.

- Each proposal must contain at least 2,000 words.

\subsection{Procedures for data collection and analysis}

This corpus-based research mainly concentrates on investigating the use of phrasal verbs in 19 MA research proposals. Moreover, the study is an attempt to find out the functions of the phrasal verbs used in 19 MA research proposals in terms of syntax and semantics. With respect to the syntax functions, the functions of phrasal verbs are explored in terms of the transitivity, intransitivity, separability and inseparability. Concerning semantics, non-idiomatic, semiidiomatic and fully idiomatic meanings of phrasal verbs are focused.

To achieve this objective, quantitative analysis was first conducted to investigate the frequency of phrasal verbs to identify the use of phrasal verbs in the research proposals by M.A. students. In the study, the lists of the most commonly used phrasal verbs and the least used phrasal verbs were also explored and then compared with the top 100 Phrasal Verb Lemmas in BNC by Gardner and Davies (2007). AntConc 3.7.8w (2018) was used to capture the use of the most frequent adverbial particles and the most frequent lexical verbs as listed above in 19 MA students' research proposals. Counts were made of total in order to investigate the use of phrasal verbs in MA students' research proposals. The quantitative analysis includes keywords, collocates and concordance line analysis. So as to create keyword lists, AntConc first took all the corpus and made a list of every word that appeared in it and the times it appeared. Afterwards, collocate analysis was implemented by picking specific lexical verbs as well as their lexical verb lemmas to analyze thoroughly about the use of phrasal verbs. When a lexical verb was statistically more relevant to the adverbial particles of the corpus, it was added to that corpus keyword list. If a lexical verb was not statistically relevant to either corpus, it was left off the lists. Concordance lines, or key words in context, were rather similar to collocates to help the researcher observe the word as it appeared in the text files. They were, however, longer than collocates and showed a snippet of each sentence in which the target word appeared. Doublecheck was employed in order to increase the reliability of data analysis. Two double checkers and researchers had to reach to an agreement level of reliability (over 95\%).

The qualitative data analysis was then used to provide examples taken from the 19 research proposals.

\section{Results and discussion}

\subsection{Results}

4.1.1 The use of phrasal verbs in English Applied Linguistics research proposals

The M.A. students' research proposals are classified into 5 main categories, including TESOL Methodology, Discourse Analysis, Linguistics, Translation, and Literature. As can be seen in Table 2, Methodology accounted for the highest number of phrasal verbs with $113(0.358 \%)$, followed by Discourse Analysis with 59 occurrences of phrasal verbs $(0.128 \%)$ and Linguistics with 46 occurrences of phrasal verbs $(0.102 \%)$. The number of phrasal verbs in Translation and Literature were the two 
lowest with $7(0.017 \%)$ and $10(0.051 \%)$, respectively. Similarly, when it comes to the comparison of the frequency of phrasal verbs in the 5 categories, Methodology ranked first with 356 phrasal verbs, followed by Discourse Analysis (127) and Linguistics (101). The two lowest frequencies of phrasal verbs were Translation (17) and Literature (15). In conclusion, the frequencies of phrasal verbs were distinctive in the 5 categories. Moreover, participants of this study tended to use more phrasal verbs in TESOL Methodology, whose frequency is approximately two-third phrasal verbs of Discourse Analysis, ranking second in Table 2 and 23 times higher than Translation and Literature.

Table 2. The number of phrasal verbs

\begin{tabular}{|c|c|c|c|}
\hline Type & $\begin{array}{l}\text { Number of } \\
\text { Phrasal verbs }\end{array}$ & $\begin{array}{c}\text { Frequency of Phrasal } \\
\text { verbs }\end{array}$ & $\%$ in the whole types \\
\hline TESOL Methodology & 113 & 356 & 0.358 \\
\hline Discourse analysis & 59 & 127 & 0.128 \\
\hline Linguistics & 46 & 101 & 0.102 \\
\hline Translation & 7 & 17 & 0.017 \\
\hline Literature & 10 & 15 & 0.051 \\
\hline Total & 235 & 618 & $100 \%$ \\
\hline
\end{tabular}

List of the 10 most common phrasal verbs used

Ten most commonly used phrasal verbs were listed as follows. As can be seen in Table 3, FIND OUT ranked first with 69 times of occurrences, accounting for $17.9 \%$ of phrasal verbs used in 19 research proposals by Vietnamese M.A. students. BASE ON, REFER TO and RELATE TO accounted for 59, 51 and 45 of occurrences, making up to $15.3 \%, 13.2$ $\%$ and $11.6 \%$ respectively. The next phrasal verbs of the 10 most common phrasal verbs list in the M.A. research proposals triggered by DEAL WITH and CARRY OUT with the same number (34) and percentage (8.8\%). CONSIST $\mathrm{OF}$, which accounts for 30 occurrences, signals up to $7.8 \%$. Making up of $5.7 \%$ and $5.4 \%$ respectively, DEPENDING ON and POINT OUT ranked eighth and ninth respectively in the list. The least used phrasal verb in the top ten list is CONTRIBUTE TO with 20 occurrences, accounting for only $5.2 \%$. The number of top ten used phrasal verbs was more than half of all phrasal verbs used in M.A. research proposals, making up of $62.5 \%$.

In comparison with the most frequent adverbial particles and lexical verbs in phrasal verbs through gathering the data from $\mathrm{BNC}$ which were conducted using 100-million-word British National Corpus (BNC) by Gardner and Davies (2007), the results from this study showed that only 2 phrasal verbs (CARRY OUT and POINT OUT) appeared in the frequency and coverage of top 100 Phrasal Verb Lemmas in BNC by Gardner and Davies (2007).

Table 3. List of the 10 most common phrasal verbs used

\begin{tabular}{ccc}
\hline Phrasal verbs & Number & $\%$ \\
\hline Find out & 69 & 17.9 \\
Base on & 59 & 15.3 \\
Refer to & 51 & 13.2 \\
Relate to & 45 & 11.6 \\
Deal with & 34 & 8.8
\end{tabular}




\begin{tabular}{ccc}
\hline Phrasal verbs & Number & $\%$ \\
\hline Carry out & 34 & 8.8 \\
\hline Consist of & 30 & 7.8 \\
\hline Depend on & 22 & 5.7 \\
\hline Point out & 21 & 5.4 \\
\hline Contribute to & 20 & 5.2 \\
\hline Total & 385 & 62.5 \\
\hline
\end{tabular}

List of the least common phrasal verbs used

In terms of the least common phrasal verbs used in M.A. research proposals, there were 30 phrasal verbs used only once in 19 research proposals such as ADD TO, BRING INTO, CLOSE DOWN, COPE WITH, COUNT FOR, COME FROM, COME OUT, DECIDE ON, DEMAND ON, DRESS UP, GET BACK, GO UP, HEAD OFF, INTERFERE WITH, LOOK INTO, LOOK UP, PICK OUT, SEEK OUT, SET APART, SET OUT, SET UP, SHAPE UP, SORT OUT, SPEAK OUT, STAND FOR, STIR UP, RUN THROUGH, TAKE ON, THINK ABOUT, WORK ON. Among 30 phrasal verbs mentioned above, only 6 phrasal verbs, including SET UP (3), COME OUT (13), SET OUT (18), GET BACK (20), LOOK UP (26) and PICK OUT (75) were on the list of top 100 Phrasal Verb Lemmas in BNC by Gardner and Davies (2007).

List of the phrasal verbs for Person Test of English (PTE) academic used

Based on the phrasal verbs for PTE academic, only 12 phrasal verbs used in 19 research proposals are listed as in Table 4, including FIND OUT, CARRY OUT, DEAL WITH, POINT OUT, RELY ON, FIGURE OUT, LOOK FOR, GET UP, SET UP, MAKE UP, MIX UP and WORK OUT. Among these phrasal verbs, FIND OUT, CARRY OUT, DEAL WITH and POINT OUT were utilized more often than the others. However, the percentage in total was rather low with only $8.74 \%$ when compared with that of the phrasal verbs used in 19 research proposals.

Table 4. List of the phrasal verbs for PTE academic used

\begin{tabular}{ccc}
\hline Phrasal verbs & Number & $\%$ \\
\hline Find out & 15 & 2.42 \\
Carry out & 11 & 1.78 \\
Deal with & 8 & 1.29 \\
\hline Point out & 4 & 1.13 \\
Rely on & 2 & 0.64 \\
Figure out & 2 & 0.32 \\
\hline Look for & 1 & 0.32 \\
\hline Get up & 1 & 0.16 \\
\hline Set up & 1 & 0.16 \\
Make up & 1 & 0.16 \\
\hline Mix up & 1 & 0.16 \\
\hline Work out & 54 & 0.16 \\
\hline Total & & 8.74 \\
\hline
\end{tabular}




\subsubsection{The distribution of phrasal verbs in} five major categories

When it comes to the comparison of the distribution of phrasal verbs in five major categories, including Methodology, Discourse Analysis, Linguistics, Literature and Translation, it can be noticed from table 5 that the highest distribution of phrasal verbs was in Methodology with 229 frequency of ten most common phrasal verbs. Additionally, the frequency of phrasal verbs distributions in Discourse Analysis and Linguistics followed with 72 and 54 respectively. The two lowest frequency of phrasal verbs distributions were in Translation and Literature with 15 and 7 respectively. Furthermore, while some phrasal verbs were in the top list in one category, they seldom appear in the others. For example, FIND OUT was the most popular phrasal verb in Methodology; however, in Literature M.A. students did not use it in their research proposals. DEPEND ON only occurred in Methodology and Discourse Analysis. Only CONTRIBUTE TO, which was on the tenth place in the 10 most common phrasal verb list, was distributed in all 5 categories. In conclusion, while M.A. students of this study seemed to utilize phrasal verbs more often in Methodology, they had a tendency to avoid using them in Literature and Translation.

Table 5. Distribution of phrasal verbs in five major categories

\begin{tabular}{|c|c|c|c|c|c|}
\hline Phrasal verbs & $\begin{array}{c}\text { TESOL } \\
\text { Methodology }\end{array}$ & $\begin{array}{l}\text { Discourse } \\
\text { Analysis }\end{array}$ & Linguistics & Literature & Translation \\
\hline Find out & 42 & 8 & 17 & 0 & 2 \\
\hline Base on & 39 & 11 & 3 & 2 & 4 \\
\hline Refer to & 36 & 3 & 2 & 0 & 4 \\
\hline Relate to & 19 & 17 & 9 & 0 & 0 \\
\hline Deal with & 30 & 2 & 0 & 2 & 0 \\
\hline Carry out & 17 & 9 & 7 & 0 & 0 \\
\hline Consist of & 18 & 1 & 7 & 0 & 4 \\
\hline Depend on & 10 & 12 & 0 & 0 & 0 \\
\hline Point out & 12 & 3 & 3 & 3 & 0 \\
\hline Contribute to & 6 & 6 & 6 & 1 & 1 \\
\hline Total & 229 & 72 & 54 & 8 & 15 \\
\hline
\end{tabular}

4.1.3 Functions of the phrasal verbs in English Applied Linguistics research proposals

Functions of the phrasal verbs in terms of syntax

As can be seen in Table 6, it is noticeable that in terms of syntax, the phrasal verbs function differently in four terms: transitivity, intransitivity, separability and inseparability (Lessard-Clouston, 1993). In terms of transitivity and intransitivity, phrasal verbs seemed to dominate when functioning as transitivity with over $98.4 \%$. Participants avoided using phrasal verbs in intransitivity with only $1.6 \%$. For instance, in Methodology and Discourse Analysis, the occurrences of transitive phrasal verbs were more than 354 and 126 respectively while those of intransitive ones were only 4 and 1 . Specifically, in Translation and Literature they even did not utilize any intransitive phrasal verbs in their research proposals. With respect to the separability and inseparability in phrasal verbs, they expressed strong preference for inseparability with more than $94.9 \%$ while separable phrasal verbs were only $5.1 \%$, with 18 and 11 phrasal verbs in Methodology and Discourse Analysis. It is evident that the use of inseparable phrasal verbs was 19 times higher than that of separable ones. 
Table 6. Functions of the phrasal verbs in terms of syntax

\begin{tabular}{|c|c|c|c|c|}
\hline \multirow{2}{*}{ Categories } & \multicolumn{4}{|c|}{ Syntax } \\
\hline & Transitivity & Intransitivity & Separability & Inseparability \\
\hline TESOL Methodology & 354 & 4 & 18 & 340 \\
\hline Discourse analysis & 126 & 1 & 11 & 116 \\
\hline Linguistics & 96 & 5 & 1 & 100 \\
\hline Translation & 17 & 0 & 1 & 16 \\
\hline Literature & 15 & 0 & 0 & 15 \\
\hline Total & 608 & 10 & 31 & 587 \\
\hline Percent & $98.4 \%$ & $1.6 \%$ & $5.1 \%$ & $94.9 \%$ \\
\hline
\end{tabular}

In order to have a closer observation into the functions of phrasal verbs used in M.A. research proposals, the qualitative data are taken into account. Here are some examples taken from the M.A. research proposals.

It is noticeable that the M.A. students used most of phrasal verbs in transitive form as in the following examples:

Therefore, researcher will do the exact investigation at specific areas and analyze the surveys' result so that researcher can find out better and more suitable solutions to train and foster secondary English teachers. (RP1)

There are many definitions of errors coming from a variety of authors with different points of view. (RP2)

Based on this theoretical foundation, I will choose a research methodology to examine the semantic, syntactic and cultural features of idioms containing human internal body parts in English and Vietnamese. (RP7)

This chapter consists of the background to the study and the aims of the study. (RP11)

In 19 M.A. research proposals, there were only 10 intransitive phrasal verbs, none of which was used in Translation and Literature.

Researchers might wish to obtain a more complete picture, for example, of what goes on in a particular classroom or school. (RP16)

Besides, the significance and scope of the study will be coming up at the end of the introduction. (RP15)
However, in some cases, the phrasal verb CARRY OUT was sometimes used in both transitive and intransitive forms as follows:

The research is carried out to find out the way to translate names of popular Vietnamese dishes into English. (RP1)

In order to prepare the base for the research, I proceeded to carry out the tasks as follows. (RP3)

In this study, participants had a tendency to keep most phrasal verbs in 19 research proposals inseparable. Here are some examples:

Writers do not openly publicize their ideas, but build up the imagery that is evocative for the reader to draw the hidden meaning. (RP19)

In order to prepare the base for the research, I proceeded to carry out the tasks as follows. (RP2)

Only some phrasal verbs such as APPLY TO, BRING INTO, BRING DOWN, CONCENTRATE ON, DISTRIBUTE TO, DRAW INTO, DEAL WITH, PUT IN, PUT INTO, PUT OUT, STIR INTO, TAKE INTO were utilized in separable forms as mentioned in the examples below:

Long and detailed explanations of the intricacies of grammatical rules and forms are supplied for students to memorize and apply the syntactic rules to other examples. (RP3) 
Then the researcher will distribute the test papers to all the students. (RP11)

After that, they put them in the reading and thus can understand their meanings. (RP 16).

Notwithstanding, some of the phrasal verbs were used in both separable and inseparable forms such as BASE ON, TURN INTO, CONTRIBUTE TO, PUT IN, DEPEND ON, CLASSIFY INTO, REFER TO, TAKE INTO, DISCUSS WITH. Some of the following examples were clarified as follows:

Accordingly, English intonation based on the expression of different pitches and the phenomenon of prosody in speech. (RP6)

The recorded patterns marked in the previous step will be compared directly or divided into groups based it on the Random function in the Excel program. (RP6)

In the integrated period, the school also shows special concern for training English majors who have expert translation skill as well as other skills of English so that they are able to contribute their own real linguist abilities to the society's development. (RP11)

Finally, the thesis is making deduction from the data about the linguistic expression contributing to Bob Dylan's success in conquering the world. (RP8)

Functions of the phrasal verbs in terms of semantics

With respect to semantic meanings, phrasal verbs are divided into three subcategories: nonidiomatic, semi-idiomatic and fully idiomatic meanings. It is evident from Table 7 that M.A. students tended to use phrasal verbs with semiidiomatic and fully idiomatic meanings with $51.2 \%$ and $43.4 \%$ rather than non-idiomatic ones with merely $4.5 \%$. Interestingly, the fully idiomatic meanings in Methodology were the highest while the highest semantic meanings of the other 4 categories were semiidiomatic meanings. Moreover, there were no non-idiomatic meanings in Translation and Literature.

Table 7. Functions of the phrasal verbs in terms of semantics

\begin{tabular}{|c|c|c|c|}
\hline \multirow{2}{*}{ Categories } & \multicolumn{3}{|c|}{ Semantics } \\
\hline & non-idiomatic & semi-idiomatic & fully idiomatic \\
\hline TESOL Methodology & 17 & 168 & 173 \\
\hline Discourse analysis & 9 & 65 & 53 \\
\hline Linguistics & 2 & 66 & 33 \\
\hline Translation & 0 & 12 & 5 \\
\hline Literature & 0 & 11 & 4 \\
\hline Total & 28 & 322 & 268 \\
\hline Percent & $4.5 \%$ & $52.1 \%$ & $43.4 \%$ \\
\hline
\end{tabular}

Only some phrasal verbs were used with non-idiomatic meanings as follows:

"When the ship comes in" is another impressive song released in 1963 with twenty other works. (RP19)

Internal factors are those that the individual language learner brings with him or her to the particular learning situation. (RP17)

In terms of semi-idiomatic meanings,
M.A. students tended to use more phrasal verbs of this categories than the other two. Below are some examples of the use of phrasal verbs.

The objectives of this study are to find out the kinds of cohesive devices used in short stories of O'Henry. (RP19)

It can be said that error is related to the competence factor. (RP1) 
MA students also had preference to utilize phrasal verbs with fully idiomatic meanings in all 5 categories of the research proposals. Here are some examples:

The researcher expects to point out the traits of isolated expression in Hemingway's characters and compare them with the expression in the others' works. (RP19)

It will take about eight months to carry out the research. (RP3)

\subsection{Discussions}

The results of the study have shown that participants of this study seem to avoid using phrasal verbs in the M.A. research proposals. They prefer to use one-word verbs in their research proposals. Such finding is in line with the findings of some previous studies conducted by Dagut and Laufer (1985); Hulstijn and Marchena (1989); Laufer and Eliasson (1993), all of whose research showed that students seemed to avoid using phrasal verbs, instead they preferred to use one-word equivalents. Furthermore, in the top ten commonly used phrasal verbs in M.A. students' research proposals, only two of which appeared in the top 100 Common Phrasal Verbs in BNC by Gardner and Davies (2007). In the top least common phrasal verbs used in M.A. research proposals, there appeared only 6 phrasal verbs listed in the top 100 Phrasal Verb Lemmas in BNC by Gardner and Davies (2007). Moreover, the findings of the study were different from that of Faharol, Norlizawati and Hifzurrahman (2011). While the students in Malaysia preferred both using phrasal verbs and one-word counterparts and avoided unfamiliar phrasal verbs, MA students in Vietnam appeared to concentrate more on using one-word verbs and used some unfamiliar phrasal verbs in writing their research proposals. In comparison with Liao and Fukuya's research (2002), both
Vietnamese and Chinese advanced learners expressed not much preference in using phrasal verbs. Moreover, whereas Chinese learners drew their attention of semantic functions of phrasal verbs into translation, Vietnamese students' attention was different as they used various type of semantic nature of phrasal verbs in TESOL Methodology.

In terms of the functions of the phrasal verbs, the syntax and semantics of phrasal verb were analyzed. With respect to the syntactic functions of phrasal verbs, participants prefered to use transitive phrasal verbs rather than transform it into intransitive phrasal verbs. In the same line of thinking, they preferred using inseparable forms to separable forms of phrasal verbs. Both intransitive and inseparable forms of phrasal verbs were utilized in much higher frequencies than transitive and inseparable forms. Among the three meanings mentioned in the semantic functions of phrasal verbs, participants expressed no preferences in using phrasal verbs with non-idiomatic meanings. Instead they paid much interest in using semiidiomatic and fully-idiomatic meanings of phrasal verbs. The results of this study were, in some ways, equivalent to those in Rong's study (2015), which showed that the semantic features had a great impact on the use of phrasal verbs among the Chinese learners. It can be concluded that due to the complexity of the use of phrasal verbs in semantic and syntactic structures, students had a tendency to choose single verbs instead of phrasal verbs in their writing (Dagut \& Laufer 1985; Laufer \& Eliasson 1993). Similarly, LessardClouston (1993) reveals some reasons why non-native students find it difficult to utilize phrasal verbs. First of all, students are confused of the meaning of the phrasal verbs as they usually identify the meaning separately from each component: verb and 
particle(s). Only in some cases do students find the meaning of the phrasal verbs by the combination of the two or more components in the phrasal verbs. The meanings of phrasal verbs vary when they are combined together; therefore, it is rather difficult for students to get the close meanings of the phrasal verbs even when they look them up in the reliable dictionary. Furthermore, "perhaps one of the most difficult aspects of phrasal verb form, meaning and use is that there are often distinctions between similar two- and threeword verbs" (Lessard-Clouston, 1993, p. 6-7). With respect to syntactic function, she adds that phrasal verbs may be used differently in various positions such as transitivity, intransitivity or seperability or inseperability.

Participants in this study who are all M.A. students of English Applied Linguistics seem to avoid using phrasal verbs in their research proposals. The results of the study showed that the total number of phrasal verbs used in research proposals was rather low. Instead, the students used more one-word verbs, which means they have a tendency to avoid using phrasal verbs in their M.A. research proposals. Moreover, the academic phrasal verbs used in 19 research proposals were rather low. One of the possible explanations is due to the difficulties that they encountered in using phrasal verbs. As Folse (2004) indicates that there are two difficulties that non-native students face when using phrasal verbs. First, it is not equivalent to know the separating parts of phrasal verbs to comprehend their whole meanings. Thus, students are not very keen on exploring the meanings of the phrasal verbs. Secondly, non-native students are required to understand the meaning of the more frequent phrasal verbs owing to their high level of occurrence. Therefore, in the same line with Becker (2014) participants with high level of English proficiency also have a tendency to avoid using phrasal verbs.

As discussed that phrasal verbs play important roles in English teaching and learning acquisition, it is not easy for EFL learners to use and understand English without understanding phrasal verbs. In this study, it is found that there is a limited number of academic phrasal verbs used in 19 research proposals. It can be concluded that due to the complexity in the semantic and syntactic functions of phrasal verbs, students have a tendency to avoid using phrasal verbs in their research proposals.

\section{Conclusion}

The results of the study have shown that participants in this study seem to avoid using phrasal verbs in their M.A. research proposals. It is noticeable that they do not use common phrasal verbs in the top 100 common phrasal verbs list. Moreover, the distributions of the top ten common phrasal verbs used in five categories including TESOL Methodology, Discourse Analysis, Linguistics, Literature and Translation are not equal. M.A. students seem to utilize more phrasal verbs in Methodology and less phrasal verbs in Literature and Translation. In terms of syntax, Vietnamese M.A. students have a tendency to use more transitive and inseparable phrasal verbs in their research proposals. With respect to semantics, they tend to use semi-idiomatic and fully-idiomatic meanings rather than nonidiomatic ones.

Although many researchers such as Gardner and Davis (2007) and Ellis (1985) agree that phrasal verbs play an important role in linguistics, students seem to avoid using them regularly. It is hoped that the findings of this study may partly contribute to enhancing Vietnamese students' using more phrasal verbs in their writing. 
An obvious limitation of the study is the size of the data since a larger data would allow more precise observations to be made and the materials for each category were not distributed evenly.

\section{References}

Altenberg, B. (1998). On the phraseology of spoken English: the evidence of recurrent word combinations. In A. P. Cowie (Ed.), Phraseology: Theory, analysis and applications (pp. 101-122). Oxford: Clarendon Press.

Becker, A. (2014). Avoidance of English Phrasal Verbs: Investigating the Effect of Proficiency, Learning, Context, Task Type and Verb Type, Asian Journal of English Language Teaching, 24, 1-33.

Biber, D., Johansson, S., Leech, G., Conrad, S., \& Finegan, E. (1999). Longman grammar of spoken and written English. London: Longman.

Börjars, K., \& Burridge, K. (2010). Introducing English grammar (2nd ed.). London, England: Hodder Education.

Celce-Murcia, M., \& Larsen-Freeman, D. (1999). The grammar book: An ESL/EFL teacher's course. Boston: H \& H Publishers.

Cornell, A. (1985). Realistic goals in teaching and learning phrasal verbs. International Review of Applied Linguistics in Language Teaching, 23(4), 269-280.

Collins Cobuild Dictionary of Phrasal Verbs, (2000). UK: Harper Collins Publishers.

Dagut, M. \& Laufer, B. (1985). “Avoidance of phrasal verbs: A case for contrastive analysis". Studies in Second Language Acquisition, 7(1), 73-79.

Davies, M. (2009). The 385+ million word corpus of contemporary American English (1990-2008+): Design, architecture, and linguistic insights. International Journal of Corpus Linguistics, 14, 159-190.

Downing, A., \& Locke, P. (2006). English grammar: A university course (2nd ed.). New York, NY: Routledge.

Faharol, Z. ,Norlizawati, G. , Hifzurrahman, R. (2016). In proceedings of Malaysian Technical Universities
International Conference on Engineering \& Technology. MUiCET 2011. 13 - 15 November, Malaysia.

Fletcher, B. (2005). "Register and phrasal verbs". MED Magazine 33(4), 212-224.

Folse, K. S. (2004). Vocabulary myths: Applying second language research to classroom teaching. Ann Arbor, MI: University of Michigan Press.

Gardner, D., \& Davies, M. (2007). Pointing out frequent phrasal verbs: A corpus-based analysis. TESOL Quarterly, 41, 339-359.

Garnier, M., and N. Schmitt. 2015. The PHaVE list: a pedagogical list of phrasal verbs and their most frequent meaning senses. Language Teaching Research 19(6). 645-66. doi:10.1177/1362168814559798

Garnier, M., and N. Schmitt. 2015. The PHaVE list: a pedagogical list of phrasal verbs and their most frequent meaning senses. Language Teaching Research 19(6). 645-66.

Garnier, M., and N. Schmitt. 2015. The PHaVE list: a pedagogical list of phrasal verbs and their most frequent meaning senses. Language Teaching Research 19(6). 645-66. doi:10.1177/1362168814559798

Garnier, M., and N. Schmitt. 2015. The PHaVE list: a pedagogical list of phrasal verbs and their most frequent meaning senses. Language Teaching Research 19(6). 645-66. doi:10.1177/ 1362168814559798

Garnier, M., and N. Schmitt. 2015. The PHaVE list: a pedagogical list of phrasal verbs and their most frequent meaning senses. Language Teaching Research 19(6). 645-66. doi: $10.1177 / 1362168814559798$

Gocsik, K. (2005). What is an Academic Paper? Dartmouth College. Retrieved from www. dartmouth.edu/ writing/materials/faculty/methods/ peergroups.shtml.

Hasbún, L. (2005). The Effect of Explicit Vocabulary Teaching on Vocabulary Acquisition and Attitude Towards Reading. Revista Actualidades Investigativas en Educación, 5(2), 1-21.

Hillard, V. \& Harris, J. (2003). Making Writing Visible at Duke University. PeerReview, 6(1), 15-17. 
Hulstijn, J. H. \& Marchena, E. (1989). “Avoidance: Grammatical or semantic causes?" Studies in Second Language Acquisition, 11, 241-255.

Huynh Ngoc Tai, Vo Thi Thuy Duong, (2015). The Application of Conceptual Metaphors In Teaching And Learning English Phrasal Verbs - The Case Of Vietnamese EFL Students. Conference: Proceedings of A TESOL Symposium in Danang, Vietnam July 2015: English Language Innovation, Implementation, and Sustainability, 183-189.

Laufer, B. \& Eliasson, S. (1993). "What causes avoidance in L2 learning: L1-L2 difference, L1-L2 similarity, or L2 complexity?" Studies in Second Language Acquisition, 13(1), 35-48.

Laufer, B. (1997). The lexical plight in second language reading: Words you don't know, words you think you know, and words you can't guess. In J. Coady \& T. 356 TESOL Quarterly, 18, 132-143 Lessard-Clouston, M. (1993). Catching on: Understanding Phrasal Verbs for ELT. ELT Teaching: A Journal of Theory and Practice, 15, 5-9.

Liao, Y. D. \& Fukuya, Y. J. (2002). Avoidance of phrasal verbs: the case of Chinese learners of English. Second Language Studies, 20(2), 71-106.

McCarthy M. \& O’Dell, F. (2004). English phrasal verbs in use. Cambridge: Cambridge University Press.

Nguyen Phu Quynh Nhu, Phan Thanh Bich Huyen (2009). Conceptual Metaphor and Its Application in Teaching Phrasal Verbs to English Majors at Thuc Hanh High School, HCMC. HCMC University of Education, 13-26.
Oxford Advanced Learner's Dictionary, (2015). Oxford: Oxford University Press.

Rong, Y. (2015). A Study of English Phrase Verb in Language Learning. The Open Cybernetics \& Systemics Journal, 9, 2128-2134

Saunders, M., Lewis, P. and Thornhill, A. (2016) Research Methods for Business Students, $7^{\text {th }}$ edn. Harlow, UK: Pearson.

Sinclair, J. (1991). Corpus, concordance and collocation. Oxford: Oxford University Press.

Stephens, A. (ed.) (2002). The English Phrasal Verb. North Carolina: University of North Carolina Press.

Sinclair, J. (1989). Collins COBUILD Dictionary of Phrasal Verbs. London, UK: Collins COBUILD.

Siyanova, A., \& Schmitt, N. (2007). Native and nonnative use of multi-word vs. one-word verbs. IRAL-International Review of Applied Linguistics in Language Teaching, 45, 119-139. http://dx.doi. org/10.1515/IRAL.2007.005

Quirk, R., Greenbaum, S., Leech, G., \& Svartvik, J. (1985). A comprehensive grammar of the English language. Harlow: Pearson Education.

Trebits, A. (2009). The most frequent phrasal verbs in English language EU documents. A corpus-based analysis and its implications. Science Direct, System, 37, 470-481.

Tran Quoc Thao, Duong My Tham (2013). Hedging: a comparative study of research article results and discussion section in applied linguistics and chemical engineering. English for Specific Purposes World, 41(14), 1-13. 


\title{
VIỆC SỬ DỤNG CỤM ĐỘNG TỪ ĐẶC NGỮ TIẾNG ANH TRONG ĐỀ CƯƠNG NGHIÊN CÚUU CỦA HỌC VIÊN CAO HỌC VIẸT NAM
}

\author{
Trần Phan Ngọc Tún ${ }^{1,}$ Trần Quốc Thao ${ }^{2}$, \\ 1. Truò̀ng THPT Bùi Thị Xuân, \\ 242 Đưòng Bùi Thị Xuân, Phưòng 2, Đà Lạt, Lâm Đồng, Việt Nam \\ 2. Đại học Công nghệ Thành phố Hồ Chí Minh, \\ 475A Điện Biên Phủ, Phưòng 25, Bình Thạn, Thành phố Hồ Chí Minh, Việt Nam
}

Tóm tắt: Cụm động từ đặc ngữ được sử dụng khá phổ biến và là một đặc trưng của tiếng Anh. Tuy nhiên, người học tiếng Anh như ngôn ngữ thứ hai hay ngoại ngữ (ESL/EFL) dường như hay tránh dùng chúng trong các bài viết học thuật, đặc biệt là viết về ngôn ngữ học ứng dụng tiếng Anh. Nghiên cứu này tìm hiểu việc sử dụng cụm động từ đặc ngữ trong đề cương nghiên cứu của học viên cao học Việt Nam đang học tập tại một trường đại học ở Việt Nam. 19 đề cương nghiên cứu của học viên được lựa chọn làm ngữ liệu cho nghiên cứu này bao quát 5 chủ đề lớn là Phương pháp giảng dạy tiếng Anh cho người phi bản ngữ (TESOL), Phân tích diễn ngôn, Ngôn ngữ học, Văn học và Dịch thuật. Dữ liệu được phân tích bằng phần mềm AntConc version 3.7.8. Kết quả nghiên cứu cho thấy học viên có xu hướng tránh dùng cụm động từ đặc ngữ trong đề cương nghiên cứu của mình. Hơn nữa, họ cũng không dùng nhiều cụm động từ đặc ngữ trong số 100 cụm động từ đặc ngữ phổ biến nhất trong $\mathrm{BNC}$ của Gardner và Davies (2007). Về chức năng của cụm động từ đặc ngữ, học viên cao học Việt Nam sử dụng nhiều tiểu loại khác nhau trong cú pháp cũng như ngữ nghĩa. Tuy nhiên, họ chú ý hơn đến việc sử dụng cụm động từ đặc ngữ chuyển tác và cụm động từ đặc ngữ mà giới từ/trạng từ không thể tách rời khỏi động từ cũng như cụm động từ đặc ngữ có tính thành ngữ hoặc bán thành ngữ.

Tù $\boldsymbol{k} \boldsymbol{h} \boldsymbol{a} \boldsymbol{a}$ : cụm động từ đặc ngữ, đề cương nghiên cứu, học viên cao học, cú pháp, ngữ nghĩa 